\title{
Diet Quality of Steers Grazing Three Range Sites in South Florida
}

\author{
K.R. LONG, R.S. KALMBACHER, AND F.G. MARTIN
}

\section{Abstract}

Crude protein and in vitro organic matter digestibility (IVOMD) were studied in diets of 4 or 5 esophageally fistulated steers grazing pine-palmetto (PP), fresh-water marsh (FM), or transition (T) sites. Crude protein in summer diets on FM (10.6\%) was higher $(P>0.05)$ than that on PP $(7.3 \%)$ and $T(7.3 \%)$. There were no differences among sites for diet crude protein content (7.1\%) during winter. There were no differences $(P>0.05)$ in diet IVOMD among 3 range sites in summer (46.8\%) or winter (33.7\%). Data suggest that diets selected on PP and T sites could meet protein requirements for dry cows in summer but not winter. Diets from the FM site could meet protein needs of lactating cows in summer, but in winter crude protein would be deficient for dry cows because of senescence of the major grass, Panicum hemitomon. Energy from the 3 sites in summer would be marginal for maintenance of dry cows, but in winter none of the sites would be adequate without energy supplementation.

Florida range south of $28^{\circ} \mathrm{N}$ is cut-over pine (Pinus elliottii, $P$. palustris) forest where natural tree regeneration has been sparse. Today this "flatwoods" range is a mixture of grasses, forbs, and shrubs with scattered pines (Hilmon 1964, White 1973). Three ecological types or range sites have been recognized (Hilmon 1964). First is the pine-palmetto site where prevailing vegetation is saw-palmetto (Serenoa repens) and major grass genera are Aristida, Andropogon, Panicum, and Schizachyrium. A second type is the fresh-water marsh or maidencane (Panicum hemitomon) pond, which is dispersed along natural drainageways throughout the pine-palmetto site. Finally, there exists a transition between pinepalmetto and fresh-water marsh. All three sites usually exist in a single pasture, but along major drainageways, viz the Kissimmee River Valley, large pastures often are exclusively fresh-water marsh.

On almost all Florida ranches where range is used, dry pregnant cows graze range in winter and fertilized, subtropical grasses are used by lactating cows in summer. Several studies have indicated that grasses are major components of cattle diets on ranges in the southeastern United States. Ninety percent of the diet was madeup of grasses on south Georgia wiregrass (Aristida stricta) range (Lewis and McCormick 1971). Wiregrass composed about $31 \%$ of diets in April after a winter burn but was replaced by bluestem (Andropogon spp.) in June (38\%) and September (37\%). Grasses made up 77\% of cattle diets during January to March on range at Ona, Fla., where about $50 \%$ of pasture yield was attributed to creeping bluestem (Schizachyrium stoloniferum), chalky bluestem (Andropogon capillipes), and maidencane (Kalmbacher et al. 1984).

Hand picked forage from pine-wiregrass range was found to be less than $8 \%$ crude protein with in vitro dry matter digestibility less than $40 \%$ from April to September (Lewis et al. 1975). Crude protein content of leaves of $\mathbf{4}$ grasses ranged from $4 \%$ in wiregrass to $12 \%$ in maidencane, while in vitro organic matter digestibility (IVOMD) ranged from $20 \%$ in lop-sided indiangrass (Sorghastrum secundum) to $40 \%$ in maidencane (Kalmbacher 1983). Creeping bluestem in winter averaged $4.8 \%$ crude protein and $31 \%$ IVOMD in leaves sampled after a 9-month deferment, but 60-day regrowth averaged $6.5 \%$ crude protein and $35.8 \%$ IVOMD (Kalmbacher et al. 1981). Creeping bluestem quality was at its highest 60-days after a February burn, when protein was 8 to $10 \%$ and

Authors are former graduate assistant, Department of Agronomy, University of Florida, Gainesville, 32611 ; agronomist, Ona Agricultural Research Center, Ona, Fla. 33865; statistician, Department of Statistics, University of Florida, Gainesville 32611 .

This is Florida Agr. Exp. Sta. Rep. No. 5819.

Manuscript accepted 2 April 1986.
IVOMU was 52 to $62 \%$ (Kalmbacher et al. 1985).

The purpose of this study was to measure crude protein and IVOMD in diets that were selected by esophageally fistulated cattle grazing 3 major range sites in Florida.

\section{Methods and Materials}

\section{Site Description}

The study was conducted on the University of Florida's Agricultural Research Center near Ona $\left(27^{\circ} 25^{\prime} \mathrm{N} 81^{\circ} 55^{\prime} \mathrm{W}\right)$. Climate is characterized by high humidity, long warm summers, short mild winters, and a frost-free period of approximately 275 days.

The experimental area was divided into 2 adjacent 8.1-ha pastures, each containing 3 sites or plant communities. Dry matter yield of the sites (Kalmbacher et al. 1984) and relative frequency of the major species (Long 1983) were not different between the pastures when they were compared at the same time. These data indicated the pastures were in good to excellent condition.

The pine-palmetto range type occurred on about $5.7 \mathrm{ha}(70 \%)$ of each pasture and contained such characteristic plants as creeping bluestem, lopsided indiangrass, saw-palmetto, gallberry (Ilex glabra), red root (Lachnanthes caroliniana), and yellow-eyed grass (Xyris spp.), A maidencane pond or fresh marsh comprised 1.6 ha (20\%) of each pasture. A transition area between the sites mentioned above comprised 0.8 ha ( $10 \%)$ of each pasture, and characteristic species included: chalky bluestem, creeping bluestem, low panicums (Dichanthelium spp.), carpetgrasses (Axonopus spp.), broomsedge bluestem (A. virginicus), saw-palmetto, St. John'swort (Hypericum spp.), Southern wax-myrtle (Myrica cerifera), gallberry, red root, goldenrod (Solidago fistulosa) and milkworts (Polygala spp.). A list of available plants and dry matter yield of major species has been published (Kalmbacher et al. 1984).

Soils on the pine-palmetto site were Ona and Smyrna fine sands (sandy, siliceous, hyperthermic Typic and Arenic Haplaquods, respectively). Soil on the fresh marsh was a Samsula muck (sandy, siliceous, silic-dysic, hyperthermic Terric Medisaprist). Soil on the transition site was a Basinger fine sand (sandy, siliceous, hyperthermic Spodic Psammaquent). The area was nearly level and poorly drained.

\section{Diet Sampling}

One pasture was grazed during summer and will be referred to as 'summer' pasture. The second pasture was grazed in 'winter' and will be referred to as such. The summer pasture was first grazed from 16 June to 26 Aug. 1980. During this time 101 diets were sampled from 4 esophageally fistulated Brahman-cross steers ( 325 $\mathrm{kg}): 47$ on pine-palmetto, 37 on fresh marsh, and 17 on the transition area. Forage was collected from 5 fistulated steers on the winter pasture between $12 \mathrm{Jan}$. and $15 \mathrm{Mar}$. 1981, when a total of 108 diet samples were collected ( 36 on each site).

Collections on summer pasture in the second year were made from 9 June to 15 Sept. 1981. During this time 29 diets were sampled on pine-palmetto site, and 30 on each of the other 2 sites. The winter pasture was grazed from 3 Jan. to $16 \mathrm{Mar}$. 1982 . On the pine-palmetto, transition, and fresh-water marsh sites of the winter pasture, 27,26 , and 26 diet samples were obtained, respectively.

Esophageally fistulated steers were allowed a 2-week adjustment on the study pastures prior to collection. Animals were corralled at night to aid in capture at $0800 \mathrm{hr}$, to insure appetite, and to minimize regurgitation during collection. Fistulated steers were equipped with screen-bottom collection bags, then they were hazed toward a predetermined site in the pasture being studied.

A 1.0 to $1.5-\mathrm{kg}$ sample of ingested forage was usually obtained once per day in 15 to 20 minutes. The fistulated steers were herded 
back to the pen after collections were made, collection bags removed, and cannulae replaced. Steers were fed 0.5 to $1.0 \mathrm{~kg} / \mathrm{steer}$ (summer or winter, respectively) of mixed grain, which served to maintain their body condition and act as an enticement to return to the corral. Minerals and water were provided ad libitum. Animals were released after collections but penned and fed the same amounts in evening.

Diets collected by steers were spread on screen frames, dried at $50^{\circ} \mathrm{C}$ for 24 hours, and ground $(0.5-\mathrm{mm}$ mesh). Samples were analyzed for crude protein (Gallaher et al. 1976, Isaac and Johnson 1976) and IVOMD (Moore and Mott 1974, 1976).

Nonfistulated steers were used during collection periods to assure uniform grazing and provide additional grazing pressure. Stocking rates in 1980 and 1981 (including nonfistulated steers) for summer and winter pastures were 55 and 53 animal unit grazing days/ha, respectively. Stocking rates for these respective pastures in 1981-82 were 59 and 40 animal unit grazing days/ha.

Hand-plucked samples corresponding to major species and plant parts observed to be consumed by fistulated steers were collected during the sampling period. These samples provided crude protein and IVOMD data for major plants in the diet.

Data analysis used the general linear model (GLM) procedure of the statistical analysis system (SAS) (Helwig and Council 1979). Two pastures formed large blocks made up of 3 areas each. Each area was grazed with up to 5 steers (replications) which were sampled periodically throughout summer and winter. Handcollected forage samples were not replicated statistically.

\section{Results and Discussion}

\section{Diet Crude Protein \\ Summer}

Diet crude protein was greater $(P<0.05)$ on marsh than on pine-palmetto or transition sites, which were not different from each other (Table 1). Diet protein was greater on the marsh because

Table 1. Diet crude protein and IVOMD of five esophageally fistulated steers graxing three range sites in summer and winter. Averages of 1980-81 and 1981-82. Ona, Florida.

\begin{tabular}{|c|c|c|c|c|c|c|}
\hline \multirow[b]{4}{*}{ Pasture } & \multicolumn{6}{|c|}{ Forage Quality Index } \\
\hline & \multicolumn{3}{|c|}{ Crude protein } & \multicolumn{3}{|c|}{ IVOMD } \\
\hline & \multicolumn{6}{|c|}{ Range Site } \\
\hline & $\mathbf{P P} \mathbf{P}^{1}$ & $T$ & FM & PP & $\mathbf{T}$ & FM \\
\hline $\begin{array}{l}\text { Summer } \\
\text { Winter }\end{array}$ & $\begin{array}{l}7.3 \mathrm{~b}^{2} \\
7.0 \mathrm{a}\end{array}$ & $\begin{array}{l}7.3 \mathrm{~b} \\
7.0 \mathrm{a}\end{array}$ & $\begin{array}{r}10.6 \mathrm{a} \\
7.4 \mathrm{a} \\
\end{array}$ & $\begin{array}{c}46.8 \\
32.2 \\
\end{array}$ & $\begin{array}{c}44.6 \mathrm{a} \\
34.8 \mathrm{a} \\
*\end{array}$ & $\begin{array}{c}48.9 \mathrm{a} \\
34.0 \mathrm{a} \\
*\end{array}$ \\
\hline
\end{tabular}

IPP is pine-palmetto; FM is fresh marsh; $\mathrm{T}$ is transition between PP and FM. 2Means within a forage quality index, within a season followed by the same letter are not significantly different (Duncan's MRT, $(P<0.05)$.

* Seasons different, $P<0.05$.

of the high amount of maidencane eaten. Organic soils of the marsh supply more nitrogen than sandy soils of pine-palmetto and transition sites (Bryan 1960), and this increases forage crude protein content. Diets of cattle grazing marsh were about $91 \%$ maidencane (Kalmbacher et al. 1984), which was the dominant forage on that site. Hand-collected maidencane in June, July, and August 1980 averaged 9,10 , and $9 \%$ crude protein, respectively. In an earlier report upper leaves and stem portions similar to those eaten by cattle in this study were found to contain 8 to $12 \%$ crude protein (Kalmbacher 1983).

Crude protein content of diets from pine-palmetto and transition sites were similar (Table 1) because botanical composition of the diets was similar (Kalmbacher et al. 1984). Hand-collected samples of chalky and creeping bluestem contained 6 to $7 \%$ crude protein. Forbs constituted only $20 \%$ of the pine-palmetto and transition area diets, and hand-collected samples indicated they contained 8 to $10 \%$ crude protein. Forbs like milkworts, meadow beauty ( $R$ hexia spp), and immature goldenrod probably improved diet crude protein above that which would be observed only if grasses were eaten.

\section{Winter}

There were no differences $(P>0.05)$ in diet crude protein among the 3 sites in winter, but there was a site $X$ season interaction $(P<0.05)$ (Table 1). This was due to the decline in diet crude protein on the marsh from summer to winter. Hand-collected samples of frosted maidencane ranged from 4 to $5 \%$ crude protein in winter. Therefore, diet crude protein on the fresh marsh declined $(P<0.05)$. Crude protein content of diets from pine-palmetto and transition sites were not different within summer or winter, nor did the respective sites change over seasons. Although the fresh marsh was higher in protein content than the other sites in summer, there was no difference $(P>0.05)$ between the fresh marsh and other sites in winter.

Since grasses were low in protein in both summer and winter, diet protein in the pine-palmetto or transition areas was elevated seasonally by either forbs (summer) or shrubs (winter). Handcollected samples of chalky and creeping bluestem contained 4 to $6 \%$ crude protein in winter. Crude protein content of handcollected shrubs ranged from 5 to $6 \%$ in gallberry, 7 to $8 \%$ in saw-palmetto and 9 to $14 \%$ in wax myrtle. Forbs were usually not available from January to mid-February, but crude protein in new Solidago fistulosa growth was measured as high as $18 \%$. Grass composition of the diets remained similar from summer to winter, but forb and shrub content varied (Kalmbacher et al. 1984). The nutritional importance of protein from forbs in summer seems to have been replaced by protein from shrubs in winter, particularly new shrub growth that is usually initiated in February and March.

Nothing is known about the digestibility of protein in these diets. Crude protein digestion coefficients (lignin ratio calculations) on burned wiregrass range in Georgia varied from 10 to $30 \%$ for diets composed of many of the same species found in the present study (Hale et al. 1962).

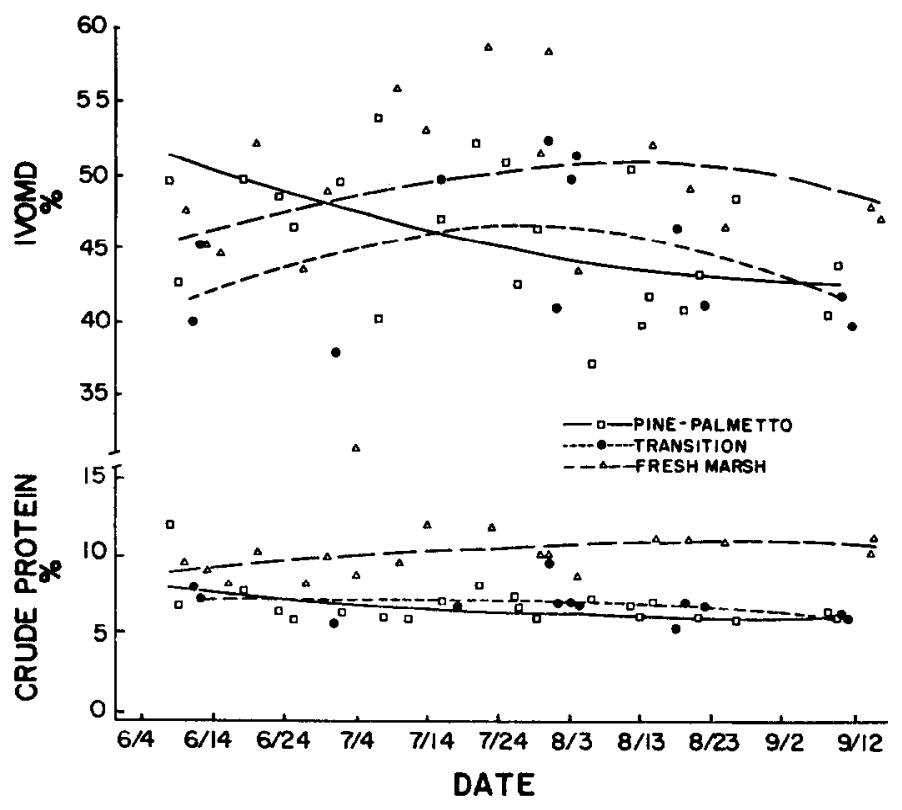

Fic. 1. Crude protein content and in vitro organic matter digestibility (IVOMD) in the diets of esophageally fistulated steers grazing 3 range sites in summer. Ona, Florida. 1980-1982.

\section{Trends in Range Sites}

The interaction for collections within sites was always significant $(P<0.05)$, but no equations could be found to fit these data. Therefore, curves were empirically determined by a procedure (Reimsch 


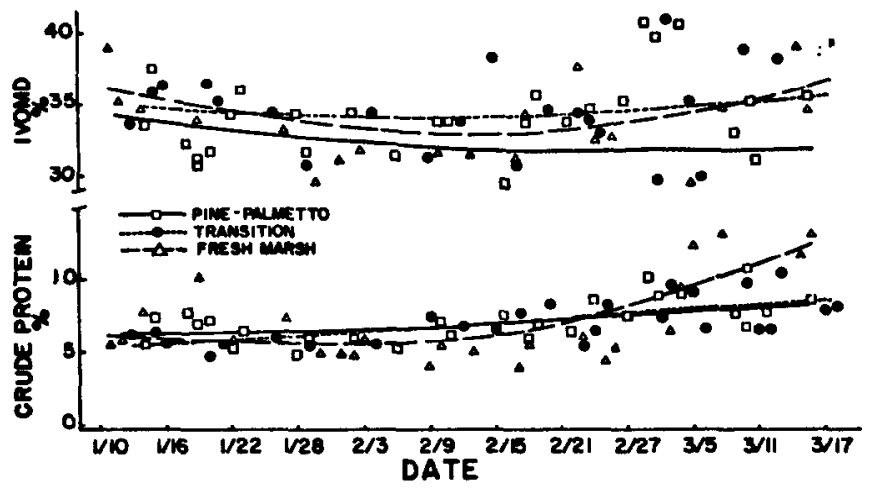

Fig. 2. Crude protein content and in vitro organic matter digestibility (IVOMD) in the diets of esophageally fistulated steers grazing 3 range sites in winter. Ona, Florida. 1980-1982.

1967) which minimized the linear combination of the sum of squares of residual fit and the integral of the sum of the second derivative (Figs. 1 and 2). Each data point is an average of diet crude protein or IVOMD over steers for a given day.

Diet crude protein on pine-palmetto and transition sites remained rather constant within summer (Fig. 1) and winter (Fig. 2), with only a slight decline of 1 to $2 \%$ from June to September. Creeping bluestem protein content in a clipping study declined 4 to $6 \%$ in August perhaps due to hot, humid weather (Kalmbacher et al. 1985). Crude protein on the fresh marsh site remained higher $(P<0.05)$ than on the pine-palmetto and transition sites throughout the summer (Table 1 and Fig. 1), but in winter the 3 sites were similar (Table 1 and Fig. 2). After mid-February crude protein in diets on the marsh site began to increase due to green-up of maidencane.

\section{Diet IVOMD}

\section{Summer}

There were no differences $(P>0.05)$ in diet IVOMD among range sites grazed in summer (Table 1). Hand-collected creeping bluestem was 44, 41, and 39\% IVOMD in June, July, and August; chalky bluestem, 32, 32, 38\%; and maidencane, 52,51 , and $44 \%$, respectively. Creeping and chalky bluestems made-up 58 and $63 \%$ of pine-palmetto and transition diets (Kalmbacher et al. 1984). Diet IVOMD remained fairly constant because of higher digestibility of forbs, which made-up 22 and $17 \%$ of pine-palmetto and transition area diets. Forbs such as red root, milk worts, and meadow beauty ranged from 37 to $60 \%$ IVOMD in summer.

\section{Winter}

Diet IVOMD values from range sites in winter were not different $(P>0.05)$ from each other, but all winter diets were lower in IVOMD as compared to respective summer diets (Table 1). Chalky and creeping bluestems ranged from 26 to $36 \%$ IVOMD, while maidencane ranged from 25 to $66 \%$. Forbs were not important diet components until late February when higher IVOMD values were associated with spring green-up.

Most shrubs were considerably lower than grasses in IVOMD. Wax myrtle and saw-palmetto were 19 to $25 \%$ and 26 to $27 \%$ IVOMD, respectively. Gallberry was an exception, as handcollected samples ranged from 44 to $51 \%$ IVOMD. Although shrubs eaten in winter may have been able to substitute for the protein contributed by forbs in summer, shrubs were not able to improve winter diet IVOMD.

\section{Trends in Range Sites}

Fresh marsh diets declined in IVOMD in August and September (Fig. 1) because of an increase in plant maturity and weathering. Fresh marsh diet-IVOMD continued to declined from about $36 \%$ (early January) to about $34 \%$ (mid-February), then increased to about $38 \%$ by mid-March with the advent of spring green-up (Fig. 2). By June diet-IVOMD was about $45 \%$ and still improving until mid August (52\%) (Fig. 1).

The pine-palmetto site steadily declined in IVOMD through summer (Fig. 1), but remained uniformly low in winter (Fig. 2). Diet IVOMD from the transition site followed a pattern similar to the marsh, increasing until late July, then declining (Fig. 1). Little change took place in diet IVOMD from January (35\%) until midMarch (36\%) (Fig. 2).

\section{Implications for Management}

Forage from both pine-palmetto and transition sites would meet crude protein requirements $(7.0 \%)$ of a dry-pregnant cow $(400 \mathrm{~kg})$ in summer during the middle third of pregnancy, but not winter during the last third of pregnancy (8.0\%) (NRC 1984). When calving occurs on range, protein should be supplemented for the lactating animal. Fresh marsh pastures should be grazed in summer because of the large decline in crude protein from summer to winter. The marsh grazed in this study $(10.6 \%)$ could meet crude protein needs of lactating cows $(10.2 \%)$ in summer, but not in winter $(7.4 \%)$.

Diet energy based on TDN estimated from IVOMD would be limiting on the range sites studied. TDN from these sites would be marginal for maintenance of a dry cow $(400 \mathrm{~kg}$, middle third pregnancy, $49 \%$ TDN) in summer, but inadequate in winter (NRC 1984). TDN would be limiting on all range sites in summer and winter for a lactating cow, which requires about 57\% TDN. Florida ranchers will need to supplement cow diets with both energy and protein if cows remain on any range site after parturition in January to May before green-up of fertilized introduced grasses.

\section{Literature Cited}

Bryan, 0.C. 1960. Soils of Florida and their crop adaptation. Bulletin No. 42. Florida Dep. Agr. Tallahassee.

Gallaher, R.N., C.O. Weldon, and F.C. Boswell. 1976. A semi-automated procedure for total nitrogen in plant and soil samples. Soil Sci. Soc. Amer. Proc. 40:887-889.

Hale, O.M., R.H. Hughes, and F.E. Knox. 1962. Forage intake by cattle grazing wiregrass range. J. Range Manage. 15:6-19.

Hilmon, J.B. 1964. Plants of the Caloosa experimental range. U.S. Forest Serv. Asheville, N.C.

Helwig, J.T., and K.A. Council. 1979. S.A.S. users guide. SAS Institute. Raleigh, N.C.

Iseac, R.A., and W.C. Johnson. 1976. Determination of total nitrogen in plant tissues using a block digester. J. Ass. Off. Anal. Chem. 69:98-101.

Kalmbacher, R.S. 1983. Distribution of dry matter and chemical constituents in plant parts of four Florida native grasses. J. Range Manage. 36:298-301.

Kalmbacher, R.S., K.R. Long, M.K. Johnson, and F.G. Martin. 1984. Botanical composition of diets of cattle grazing south Florida rangeland. J. Range Manage. 37:334-340.

Kalmbacher, R.S., F.G. Martin, and J.M.S. Andrade. 1981. Yield and quality of creeping bluestem as affected by time of cutting. J. Range Manage. 34:471-474.

Kalmbacher, R.S., F.G. Martin, W.S. Terry, D.H. Hunter, and L.D. White. 1985. Effects of clipping on burned and unburned creeping bluestem. J. Range Manage. 38:531-535.

Lewis, C.E., R.S. Lowery, W.G. Monson, and F.E. Knox. 1975. Seasonal trends in nutrients and cattle digestibility of forage on pine-wiregrass range. J. Anim. Sci. 41:208-212. 
Lewis, C.E., and W.C. McCormick. 1971. Supplementing pine-wiregrass range with improved pasture in south Georgia. J. Range Manage. 24:334-339.

Long, K.R. 1983. Evaluation of Florida native range using esophageal fistulated steers. M.S. Thesis. Univ. of Florida, Gainesville.

Moore, J.E., and G.O. Mott. 1974. Recovery of residual organic matter from in vitro digestion samples. J. Dairy Sci. 57:1258-1259.

Moore, J.E., and G.O. Mott. 1976. Fermentation tubes for in vitro digestion of forages. J. Dairy Sci. 59:167-169
NRC-1984. Nutrient requirements of domestic animals. No. 1. Nutrient requirements of beef cattle. Fifth revised ed. Nat. Acad. Sci., Nat. Res. Council. Washington, D.C.

Reimsch, C.H. 1967. Smoothing by spline functions. Numerische Mathematik 10:177-183.

White, L.D. 1973. Native forage resources and their potential p. 1-17. In: Range Res. of the Southeastern U.S., Amer. Soc. Agron. Madison, Wis. 